\title{
Light chain plasmacytoid lymphocytic lymphoma
}

\author{
ANTONIO TABILIO \\ M.D. \\ Cristina Mecucci \\ M.D.
}
Brunangelo Falini
M.D.

Massimo F. Martelli

M.D.

Istituto di Clinica Medica e Terapia Medica, Università di Perugia, Italy

\begin{abstract}
Summary
A case of plasmacytoid lymphocytic lymphoma characterized by the exclusive finding of a $\lambda$-light chain paraprotein, in the absence of heavy chains, is described. The immunoperoxidase study on bone marrow biopsy sections confirmed the production and secretion of the only $\lambda$-light chain.
\end{abstract}

\section{Introduction}

Waldenström's primary macroglobulinaemia (Waldenström, 1944) is characterized by serum IgM paraproteinaemia and pleomorphic infiltration consisting of lymphocytes, abnormal plasma cells and intermediate cell forms in the bone marrow and other tissues (McCallister et al., 1967; MacKenzie and Fudenberg, 1972). This pathological picture has been termed 'plasmacytoid lymphocytic lymphoma' by Lukes and Collins (1975) in their classification system for non-Hodgkin's malignant lymphomas. However, an identical tumour cell morphology has been observed in some patients in whom the IgM serum paraprotein is absent (Child et al., 1977; Tursz et al., 1977; Levine et al., 1980).

The patient now described presented with the cytohistological features of 'plasmacytoid lymphocytic lymphoma' but with a paraprotein belonging to the $\lambda$-light chain. Immunoperoxidase and electronmicroscopic studies are included in this report.

\section{Case report}

A 66-year-old woman presented in June 1979 with a 3-month history of progressive weakness and dyspnoea. Past history was unrevealing. Both the liver and spleen were found to be enlarged at physical examination; the liver extended $5 \mathrm{~cm}$ and the spleen $8 \mathrm{~cm}$ below the costal margin. Moderate generalized lymphadenopathy was present.

Laboratory data included: $\mathrm{Hb} \mathbf{8 \cdot 2} \mathrm{g} / \mathrm{dl}$; platelets $80 \times 10^{9} / 1$; leucocytes $5 \times 10^{9} / 1$ with $58 \%$ neutrophils, $4 \%$ monocytes and $38 \%$ lymphocytes; ESR
$4 \mathrm{~mm} / \mathrm{hr} ;$ BUN $80 \mathrm{mg} / \mathrm{dl}$; uric acid $10.8 \mathrm{mg} / \mathrm{d} \hat{\mathrm{N}}_{\mathrm{N}}$ calcium $2 \cdot 2 \mathrm{mmol} / \mathrm{l}$. SGOT, SGPT, LDH, alkalin $\overrightarrow{\vec{e}}$ phosphatase, and bilirubin were within the normas range. Total serum protein was $52 \mathrm{~g} / \mathrm{l}$ with specifis values of IgG $7.9 \mathrm{~g} / \mathrm{l}$, IgA $0.5 \mathrm{~g} / \mathrm{l} ; \operatorname{IgM} 0.34 \mathrm{~g} / \stackrel{\mathrm{P}}{\text {. }}$ Serum electrophoresis showed a sharp peak in the $\beta$ region, which was immunochemically demon\& strated to have $\lambda$ chain specificity. Bence Joner proteinuria was $20 \mathrm{~g} / 24 \mathrm{hr}$.

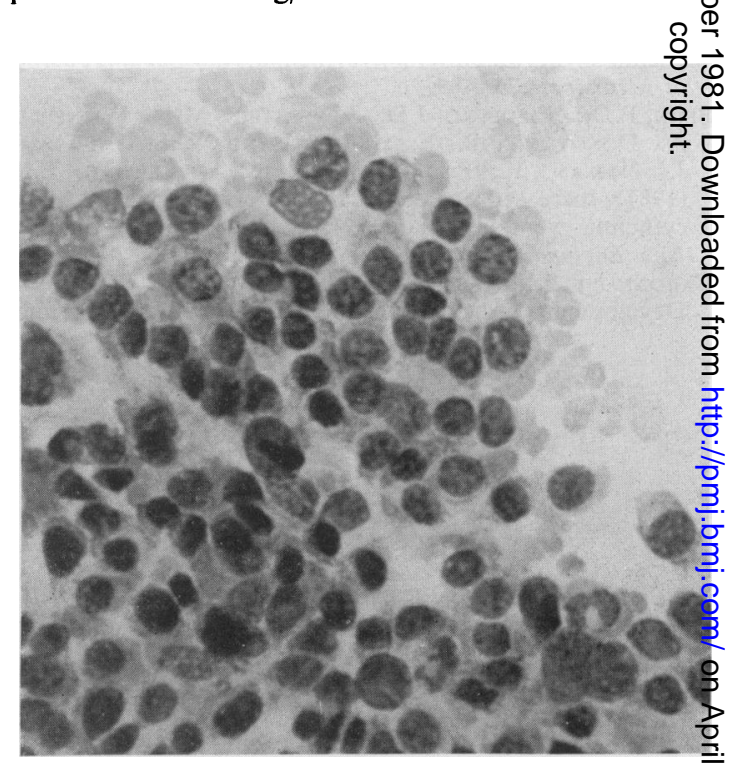

FIG. 1. Bone marrow aspirate showing infiltrate com- $\widetilde{\Omega}$ posed of lympho-plasmacytoid cells and small lympho- $\mathrm{N}$ cytes (May-Grünwald-Giemsa, $\times 400$ ).

A sternum bone marrow aspirate (Fig. 1) and $\mathrm{a} 9$ iliac crest needle bone marrow biopsy both revealed an extensive pleomorphic infiltrate mainly composed of plasmacytoid lymphocytic cells. Small lympho cytes with nuclei almost devoid of cytoplasm ang 
a few mature plasma cells were also seen. Rectal biopsy for amyloid was negative. There were no osteolytic lesions on skeletal films.

A diagnosis of plasmacytoid lymphocytic lymphoma with Bence Jones proteinaemia and proteinuria was made and treatment with chlorambucil and steroids was started. This resulted in slow but progressive improvement.

\section{Materials and methods \\ Electronmicroscopic studies}

Marrow fragments were fixed for $1 \mathrm{hr}$ in $2.5 \%$ glutaraldehyde in $0.5 \mathrm{M}$ phosphate buffer at $\mathrm{pH}$ 7.2 and post-fixed in $1 \%$ osmium tetroxide. Ultrathin sections prepared from Epon-Araldite-embedded material were stained with uranyl acetate and lead citrate and examined in a Philips EM 300 electron microscope.

\section{Immunoperoxidase studies}

Serial sections of Zenker's fixed bone marrow specimens were examined for the presence of cytoplasmic immunoglobulins by the peroxidaseantiperoxidase (PAP) method, as described by Taylor (1976). All antisera and PAP complexes used were obtained from Dakopatts A/s. 3,3'diaminobenzidine-tetra $\mathrm{HCl}$ (DAB) was purchased from BDH.

\section{Membrane markers}

Suspensions of mononuclear cells were obtained from peripheral blood by Ficoll-Hypaque density gradient centrifugation. The E-rosette test was used for identifying the $T$ cells; surface immunoglobulins were identified by direct immunofluorescence staining using $F\left(a b^{\prime}\right)_{2}$ goat polyvalent and specific anti-immunoglobulin antisera obtained from commercial sources (Aiuti et al., 1974).

\section{Results}

Ultrastructural findings

Electron microscope studies confirmed the light

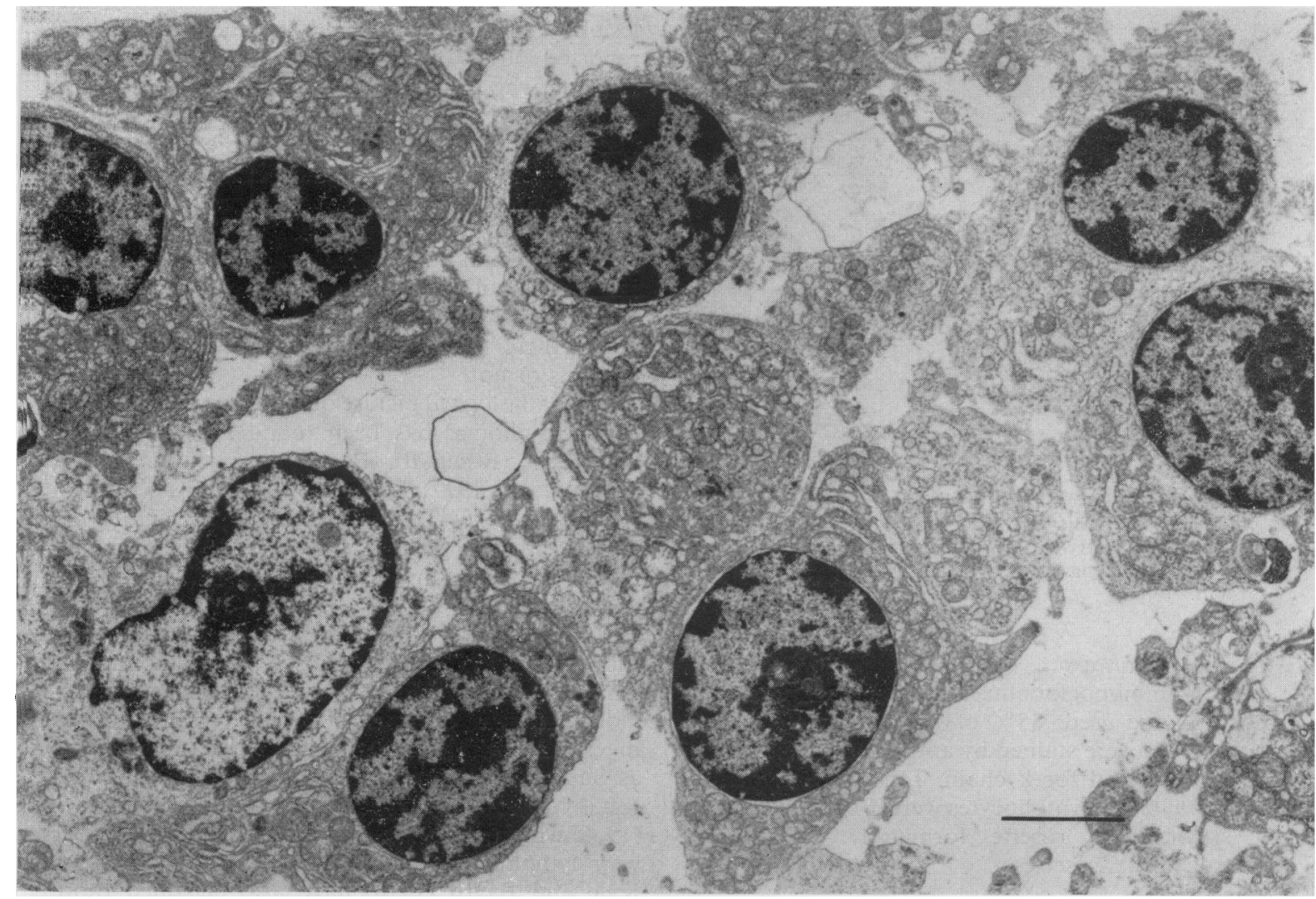

FIG. 2. Bone marrow aspirate displaying the pleomorphic features of neoplastic lymphoid cells $(\mathrm{TEM}, \times 18000$; bar represents $1 \mu \mathrm{m}$ ). 
microscopy finding of cytological pleomorphism in the bone marrow. Small and medium-sized lymphocytoid cells dominated the bone marrow infiltrate picture (Fig. 2).

A few mature plasma cells were also seen. The nuclei were spheroid, medium-sized, and displayed a degree of chromatin margination. Occasional nucleoli were also seen. Eccentric arrays of well developed rough endoplasmic reticulum occupied the scanty cytoplasm, but these were less prominent than is usual in myeloma cells. The Golgi apparatus was poorly developed.

\section{Intracellular immunoglobulins}

Immunoperoxidase staining of bone marrow specimen sections showed all lymphoid cells to contain only $\lambda$-light chain (Fig. 3). Anti- $\gamma, \alpha, \mu, \delta$, $\varepsilon$, and $\mathrm{k}$ antisera gave negative results.

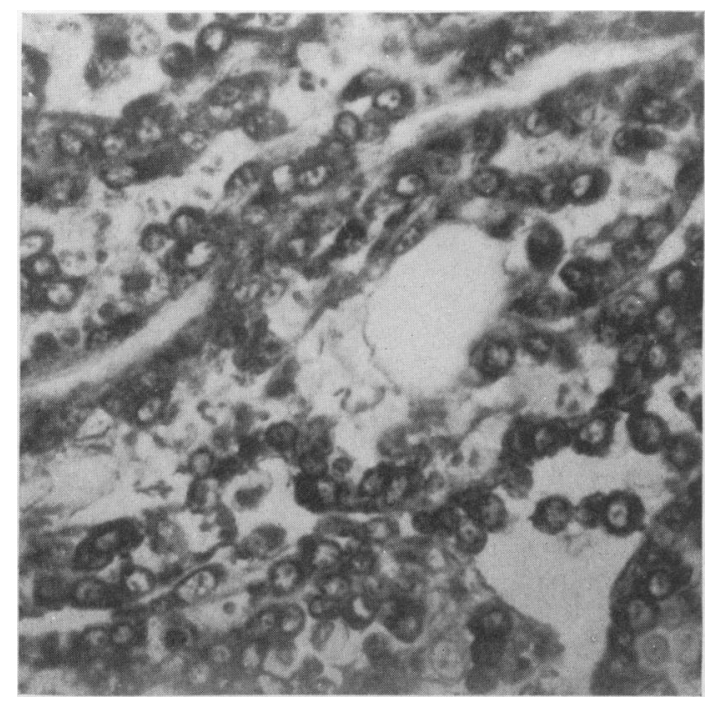

FIG. 3. Bone marrow biopsy section stained for $\lambda$-light chain by the immunoperoxidase technique. The lymphoplasmacytoid cells are seen as uniformly dark brown in the original preparation (Haematoxilin counterstain, $\times 400$ ).

\section{Membrane markers}

When immunoglobulin class-specific fluorescent antisera were used, $85 \%$ of the peripheral mononuclear cells were stained by anti $\lambda$-antibodies, while only $5 \%$ stained for $\mathrm{k}$ chain. Ten per cent. of the peripheral blood lymphocytes were T cells as defined by spontaneous rosette formation with sheep erythrocytes (E-rosettes).

\section{Discussion}

The tumour morphology in this patient was identical with the classical description of Waldes ström's macroglobulinaemia.

The findings of an isolated $\lambda$-light chain paritproteinaemia and proteinuria without concomitant IgM M component were unexpected. The boge marrow biopsy immunohistochemical study co용. firmed the results of the serum and urine immungelectrophoresis and revealed the presence of $\%$ monoclonal $\lambda$-light chain within the lymphoplasmoscytoid cells and no $\mu$ or other heavy chain deter minants. Moreover, it was demonstrated that $85 \%$ of the peripheral blood lymphocytes bore onds $\lambda$-light chain on their surface.

So far as the authors know, only 2 similar cases hape been analysed. In one, described by Tulliez, Elbzz and Tulliez (1979), the manifestations at present $\mathcal{A}_{+}$ tion and the cytohistological picture were of Waldei ström's disease, and the immunofluorescent studies confirmed that the only chain present in the plasmes cytoid lymphocytic cells was the $\lambda$-light chain. Po the other reported by Sun et al. (1979), the tumour morphology and immunohistochemical pattern were similar; however, the clinical picture at pre sentation was that of multiple myeloma (osteolyt lesions and hypercalcaemia). Levine et al. (198థ्) reported one patient (case No 7) in their recent series in whom the clinical picture at diagnosis gras characterized by high levels of plasmacytaide lymphocytic cells in the peripheral blood associated with osteolytic lesions without either splenomegaß or lymphadenopathy. The only protein anomas encountered was the presence of type $k$ Bence. Jones proteinuria. However, as no intracellular immunoglobulin study was carried out, it is nब known whether the lymphoid cells were synthesizin and if there were non-secretory heavy chain dete? minants or not.

The pathological picture of 'plasmacytoid lymph $\frac{\overrightarrow{7}}{\text { ? }}$ cytic lymphoma' has been found also in patients with IgG (Resegotti, Palestro and Coda, 197 Tursz et al., 1977; Levine et al., 1980), with Ig (Hijmans, 1975; Tursz et al., 1977; Levine et at. 1980), with IgE (Shirakura et al., 1978) with mone clonal gammopathy, or without $\mathbf{M}$ component (Levine et al., 1980).

Can plasmacytoid lymphocytic lymphomas, where monoclonal IgM serum is absent, be interpreted as. variants of the classical Waldenström's macrö globulinaemia or can they be considered as myelomas with lymphoplasmacytic morpholog as Sun et al. (1979) claimed for their patient? This last hypothesis is supported by Maldonado et $a \mathbb{E}$ (1966) who reported that myeloma cells may appeaw very lymphoid at light and electron microscopyo Kyle and Bayrd (1976) have also classified those disorders characterized by lympho-plasmacytie bone marrow infiltration and IgG type paraprotein 
aemia as multiple myeloma; whereas Levine et al. (1980) and Tursz et al. (1977) maintain that the characteristic cell infiltrates in which lymphocytes and plasmacytoid lymphocytes predominate is clearly different from that seen in multiple myeloma.

The differences in definition are more apparent than real. Those cases in which there are intermediate characteristics between Waldenström's macroglobulinaemia and multiple myeloma may well reflect a block in the maturation of lymphocytes at a certain stage of their differentiation. Indeed, the target cell for malignant transformation in multiple myeloma may also be a B-lymphocyte and this could then be responsible for the malignant myeloma cell proliferation (Salmon and Seligmann, 1974; Mellstedt, Killander and Pettersson, 1977).

\section{References}

Aiuti, F., Cerottini, J.C., Coombs, R.R.A., Cooper, M., Dickler, H.B., Fröland, S., Fudenberg, H.H., Greaves, M.F., Grey, H.M., Kunkel, H.G., Natvig, J., Preud'Homme, J.L., Rabellino, E., Rowe, D.S., SeligmanN, M., Siegal, F.P., Stjernswärd, J., Terry, W.D. \& Wybran, J. (1974) Identification, enumeration and isolation of $B$ and $T$ lymphocytes from human peripheral blood. Report of a WHO-sponsored workshop on human B and T cells. Scandinavian Journal of Immunology, 3, 521.

Child, J.A., Franklin, I.M , Warren, J.V., Cawley, J.C., Roberts, B.E., Burns, G.F. \& RoACH, T.C. (1977) Pleomorphic B cell neoplasm with monoclonal IgA secretion. A case report. Cancer, 40, 2948.

Hijmans, W. (1975) Waldenström's disease with an IgA paraprotein. Acta medica scandinavica, 198, 519.

KYLE, R.A. \& BAYRD, E.D. (1976) The Monoclonal Gammopathies. P. Thomas, C.C., Springfield.

Levine, A.M , Lichtenstein, A., Gresik, M.V., Taylor, C.R., Feinstein, D.I. \& Lukes, R.J. (1980) Clinical and immunologic spectrum of plasmacytoid lymphocytic lymphoma without serum monoclonal IgM. British Journal of Haematology, 46, 225.
Lukes, R.J. \& Collins, R.D. (1975) A functional classification of malignant lymphomas. In: The Reticuloendothelial System. (Ed by Rebuck, J.W., Berard, C.W. \& Abell, M.R.), p. 213, Williams \& Wilkins Co., Baltimore.

McCallister, B.D., Bayrd, E.D., Harrison Jr, E.G. \& McGuCKIN, W.E. (1967) Primary macroglobulinemia. Review with a report on thirty-one cases and notes on the value of continuous chlorambucil therapy. American Journal of Medicine, 43, 394.

MacKenzie, M R. \& FudenberG, H.H. (1972) Macroglobulinemia: an analysis of forty patients. Blood, 39, 874 .

Maldonado, J.E., Kyle, R.A., Brown Jr, A.L. \& Bayrd, E.D. (1966) 'Intermediate' cell types and mixed cell proliferation in multiple myeloma: electron microscopic observation. Blood, 27, 212.

Mellstedt, H., Killander, D. \& Pettersson, D. (1977) Bone marrow kinetic studies on three patients with myelomatosis. Acta medica scandinavica, 202, 413.

Resegotti, L., Palestro, G. \& Coda, R. (1977) Waldenström-like immunocytic lymphoma with IgG serum $M$ component. Acta haematologica, 58, 38.

Salmon, S.E. \& SeligmanN, M. (1974) B-cell neoplasia in man. Lancet, ii, 1230.

Shirakura, T., Takekoshi, K., Umi, M., Kanazawa, K. OKABE, H., INOUE, T. \& ImAMURA, Y. (1978) Waldenström's macroglobulinemia with IgE M component. Scandinavian Journal of Haematology, 21, 292.

Sun, N.C.J., Fishkin, B.G., Nies, K.M., Glassy, E.F. \& Car PEnTIER, C. (1979) Lymphoplasmacytic myeloma. An immunological, immunohistochemical and electron microscopic study. Cancer, 43, 2268.

TAYLOR, C.R. (1976) An immunological study of follicular lymphoma, reticulum cell sarcoma and Hodgkin's disease. European Journal Cancer, 12, 61.

Tulliez, M., Elbaz, J. \& Tulliez, M. (1979) Dysglobulinémie à chaines légères présentant les caractères clinicopathologiques d'une maladie de Waldenström. Nouvelle Revue française d'Hématologie, 21 (Suppl. 1), 100, R96.

Tursz, T., Brouet, J.C., Flandrin, G., Danon, F., Clauvel, J.P. \& SeligmanN, M. (1977) Clinical and pathologic features of Waldenström's macroglobulinemia in seven patients with serum monoclonal IgG or IgA. American Journal of Medicine, 63, 499.

WALDENSTRÖM, J. (1944) Incipient myelomatosis or 'essential' hyperglobulinemia with fibrinogenopenia-a new syndrome? Acta medica scandinavica, 117, 216. 